\title{
Ethanol Production of Biomass Rich in Sugar: Energy and Environmental Opportunity
}

\author{
N. Nedjah, N. Laskri, D. Daas, and M. Baccouche
}

\begin{abstract}
Of our days, fossil fuels, which are at the base of the oil, are scarce. In addition, the whole world knows at this time a growing commitment to a sustainable environment. Result? Use biofuel (ethanol and diesel) of biomass. The main motivation of the development of biofuels (ethanol and biodiesel) is the environmental gain potential that biofuel provide compared to petrochemical fuels.

According to the International Energy Agency (IEA), biofuel will account for $12 \%$ of global stocks of liquid fuel by 2030 , and this percentage will increase to $26 \%$ by 2050 . In 2008 , biofuel represented a little more than 1 per cent of the whole of the liquid fuels for engines.

This paper interested in the realization of the alcoholic fermentation of biomass rich in sugar; the waste of dates of two varieties; at the laboratory scale in order to optimize the performance in bioethanol per $\mathrm{kg}$ of biomass; this reaction is governed by operating conditions very critical for this our first step of work has been to determine the parameters of the good functioning of the alcoholic fermentation.

The results of our study has shown that the optimal temperature of the alcoholic fermentation is $30^{\circ} \mathrm{C}$, the $\mathrm{pH}$ range of 6-5.5, agitation is $150 \mathrm{rpm}$, the residence time of the reaction is $72 \mathrm{~h}$ and for a concentration of $300 \mathrm{~g} / \mathrm{L}$ glucose of waste soft dates of we produces a concentration of $280 \mathrm{~g} / \mathrm{L}$ of ethanol and a productivity of $3,88 \mathrm{~g} / \mathrm{L} / \mathrm{h}$ of ethanol for $165 \mathrm{~g}$ of biomass. In the case of waste dried dates of mass $173 \mathrm{~g}$, it was found for a concentration of $100 \mathrm{~g} / \mathrm{L}$ glucose, we produces $320 \mathrm{~g} / \mathrm{L}$ of ethanol with a productivity of $4,44 \mathrm{~g} / \mathrm{/} / \mathrm{h}$.
\end{abstract}

Index Terms-Bioethanol, energy, fermentation, biomass, sugar.

\section{INTRODUCTION}

Bioethanol is a renewable form of energy has high added value, it east regards as a positive solution with the problems economic and environmental caused by the vegetation wastes.

The ethanol or ethanol $\mathrm{C}_{2} \mathrm{H}_{5} \mathrm{OH}$, is obtained in a traditional way by fermentation of the glucose extracted from sugar matters (beet, canes with sugar) or by starch-based matter hydrolysis (corn, barley, but) [1].

The reaction of conversion of ethanol sugar is as follows:

$$
\mathrm{C}_{6} \mathrm{H}_{12} \mathrm{O}_{6} \longrightarrow 2 \mathrm{C}_{2} \mathrm{H}_{5} \mathrm{OH}+2 \mathrm{CO}_{2}+\text { heat }
$$

The substrate chosen for this bioconversion is an agricultural waste, made up of date scrap of fable commercial value of the western south of Algeria, of two various varieties;

Manuscript received July 6, 2017; revised September 18, 2017.

The authors are with Laboratory Physical Metallurgy and Properties of Materials, University Badji Mokhtar Annaba, Algeria (e-mail: n.nedjah@epst-annaba.dz, mostefabaccouche@yahoo.fr). these dates have the advantage of having a high sugar rate and a great tonnage [2].

This area of the great south of Algeria has an arid Saharan climate, characterized by high temperatures involving an acceleration of the maturation of dates, a dehydration and appearance of a brownish coloring of this fruit. One notes during all the year a very weak pluviometer, an intense luminosity; a strong evaporation in particular at the times of the maturation of dates and a very strong wind and very violent one [3].

Under these conditions there, one can only collect dates of less value commercial. This fruit badly developed by the farmers, and considered as an agricultural waste, can be used like substrate of alcoholic fermentation to produce a substance with strong added value (ethanol) [4].

On the level of the laboratory, one it was considered useful to start two alcoholic fermentations of musts of soft and dry date. The two fermentations was carried out by the selected yeast action (Saccharomyces cerevisiae) all that to form a wine having a color and a special savour indicator of alcohol presence. The fermentation efficiency is deduced by measurement from the physicochemical results of the analysis such: concentration in glucose, $\mathrm{pH}$, and concentration out of dry matter and finally quantity of alcohol produced [5].

The two tests have given a bioalcool of alcoholic degree of; $28^{\circ}$ for the soft date, and $32^{\circ}$ for the dry date; these results are encouraging and we believe improve this performance by the development of the distillation [6].

Of this fact and through a alcoholic fermentation and while valuing a biomass rich in sugar and low market value, we produce a bioalcool of high market value and especially considered, in our days, a renewable energy that can replace the oil in the near future[7], [8].

\section{MATERIALS AND METHODS}

\section{A. Vegetable Material (Selection of the Fermentation Substrate): Soft Date and Dry Date}

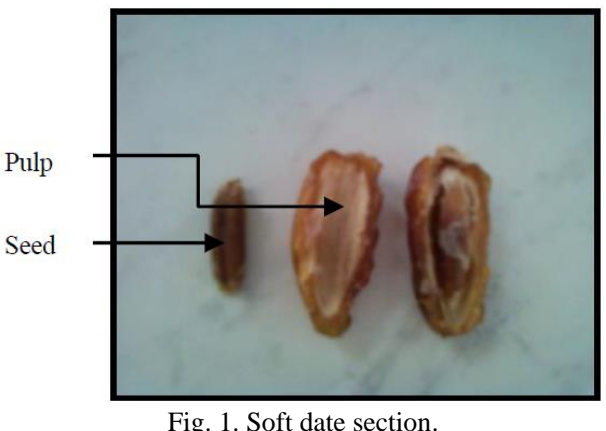

Fig. 1. Soft date section. 
The Fig. 1 and Fig. 2 present the vegetal material used in the fermentation alcoholic.

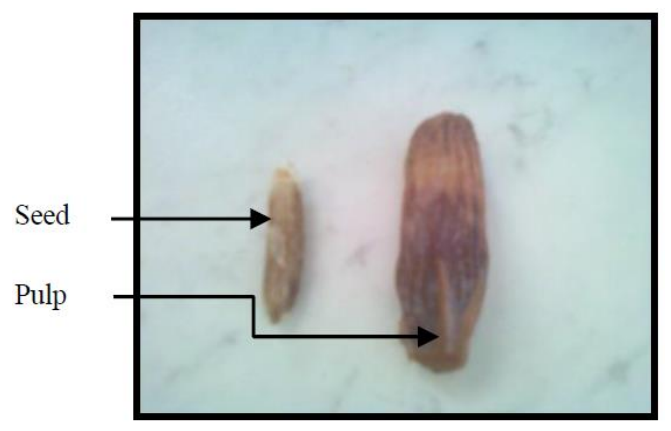

Fig. 2. Dry date section.

TABLE I: CONTENT OF SUGAR IN THE DATE PALM

\begin{tabular}{ccc}
\hline Varieties Parameters & Dry dates & Soft dates \\
Water content \% & $13.70-15.5$ & $25.40-37.3$ \\
Total sugar \% MS & $72.30-82.46$ & $79.80-87.42$ \\
Sucrose \% MS & $40.55-52.40$ & $0.9-5$ \\
\hline
\end{tabular}

The Table I illustrate the analysis of the fermentation substrate: dry and soft date.

\section{B. Production of Dates}

In Algeria: The Date Palm is grown at the level of 17 cities only, for an area of 120830 hectares. However, four main cities represent $83.6 \%$ of the national heritage phoenicicole: Biskra 23\%, Adrar 22\%, El-Oued 21\% and Ouargla 15\% [2].

In the national territory, the variety Deglet-Nour( dates fine), occupies the first place and represents $52.87 \%$ of the total production of dates [3]. The TABLE II mentions the date palms in Algeria.

In the world: the main producer countries of dates are: Egypt, Iran, Saudi Arabia, the United Arab Emirates, Pakistan, Algeria and the Sudan. The world production of dates carried out in 2004 is 5.85 million tones; the TABLE III mentions the classification of the countries of the world by date production [4].

TABLE II: DATE PALMS IN ALGERIA

\begin{tabular}{llllll}
\hline Varieties Cities & $\begin{array}{l}\text { Fine date } \\
(\text { Deglet }- \text { Nour })\end{array}$ & $\begin{array}{l}\text { Soft date } \\
(\text { Ghars })\end{array}$ & $\begin{array}{l}\text { Dry date } \\
(\text { Degla-beida })\end{array}$ & Palm date & Number of palm date \\
\hline Adrar & 0 & 0 & 2150904 & 2904150 & 2860071 \\
Biskra & 1964460 & 436530 & 748200 & 3149190 & 5802012 \\
Tamanraset & 2940 & 0 & 0 & 417140 & 167760 \\
Ourgla & 1092330 & 783850 & 193130 & 2310069 & 1130667 \\
Eloued & 1884030 & 703330 & 296300 & 2660883 & 2580238 \\
Tindouf & 350 & 24250 & 0 & 24600 & 3200 \\
Ghardaia & 377100 & 154400 & 378900 & 910400 & 631600 \\
\hline
\end{tabular}

\section{TABLE III: DATE PRODUCTION (FAO, 2004))}

\begin{tabular}{ll}
\hline Countries & Date production (quintal) \\
\hline Egypt & 1100000 \\
Iraq & 910000 \\
Iran & 880000 \\
Saoudi Arabia & 830000 \\
United Arab Emirates & 760000 \\
Pakistan & 650000 \\
Algeria & 450000 \\
Sudan & 330000 \\
Oman & 238611 \\
Libya & 140000 \\
Tunisia & 110000 \\
Morocco & 54000 \\
Yemen & 33000 \\
Mauritania & 24000 \\
Chad & 18000 \\
United States America & 18000 \\
Bahrain & 17000 \\
Qatar & 16500 \\
\hline
\end{tabular}

From the quantitative point of view, the Algerian production represents 7 per cent of the global production, but from a qualitative point of view, it occupies the first rank thanks to the variety Deglet-Nour, the more appreciated globally [2].

The morphological characters of waste soft and dry dates are defined in Table IV and Table V.
The morphological characters of the fruit of this variety are according to the origin of seed and the studied area [9].

By studying these morphological characters of anonymous dates of the area of Adrar in the laboratory; and finds us the characters following Table V [2]:

\begin{tabular}{|c|c|}
\hline Pulp & Seed \\
\hline Straight form & Straight form \\
\hline Average height & Average height \\
\hline Weight of 20 fruits $87-220 \mathrm{~g}$ & seed/ fruit : $1 / 2-2 / 3$ \\
\hline red or brown color 'Bser' & Weight of 20 seeds : $13-24 \mathrm{~g}$ \\
\hline Brown color 'tmar' & Brown color \\
\hline Pleated epicarp & Smooth surface \\
\hline No alteration & Groove shape: variable \\
\hline Soft or elastic plasticity & Center germinal pore \\
\hline Fibrous or floury texture & Long stem \\
\hline Perfumed taste & Bonding tegument \\
\hline Soft consistency & \\
\hline \multicolumn{2}{|c|}{ TABLE V: CHARACTERS MORPHOLOGICAL OF DATES DRY } \\
\hline Pulp & Seed \\
\hline Straight form & Straight form \\
\hline Average height & Average height \\
\hline Weight of 20 fruits 125.5 à $135 \mathrm{~g}$ & Weight of 20 seeds : 18 à $25 \mathrm{~g}$ \\
\hline red or brown color 'Bser' & - \\
\hline Brown color 'tmar' & - \\
\hline Dry consistency & - \\
\hline Fibrous texture & - \\
\hline Perfumed taste & - \\
\hline
\end{tabular}




\section{Biological Material}

The yeast of bakery dries (Saccharomyces cerevisiae) [7] it is preserved in a cold and dry medium. Saccharomyces cerevisiae is a micro-organism, a particular yeast among all the leavens. Its size varies from 6 to $12 \mu \mathrm{m}$ for the length and from 6 to $8 \mu \mathrm{m}$ for the width Saccharomyces can produce energy necessary to its survival and its reproduction in two different ways, according to the ambient conditions. These two modes of energy production are [10]: The aerobic way and the anaerobic way: the first is used in kitchen, while fermentation is privileged for the production of alcohol [11]. The tests of fermentation are carried out in a bioreactor of $1 \mathrm{~L}$ volume, placed in a Marie bath provided with a temperature regulator.

After several tests, one noticed that good fermentation is made at a temperature in the mesophoilic zone mésophile, of $32^{\circ} \mathrm{C}$, optimal temperature for reproduction [12].

The date scrap (dry and soft) will undergo a thermal pretreatment, it is the first stage of the process: a dilution with hot water $\left(90^{\circ} \mathrm{C}\right.$ with $\left.95^{\circ} \mathrm{C}\right)$, during an optimized time; This water rich in sugar will be used thereafter as water of dilution of must.

The following figures (Fig. 3 and Fig. 4) illustrate the two varieties of dates used.

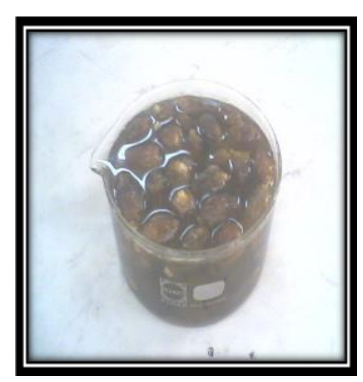

Fig. 3. Soft date

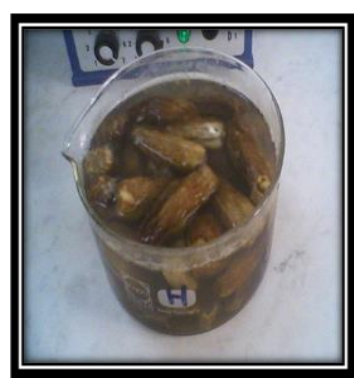

Fig. 4. Dry date.
After of elimination the stone of the dates, we start the second physical treatment, it is the crushing of the substrate. We weigh pulp and stone of the two varieties of dates; we obtain the results presented on the following Table VI:

\begin{tabular}{ccc}
\multicolumn{3}{c}{ TABLE VI: WEIGHT OF PULP AND CORE } \\
\hline Variety & soft & dry \\
\hline Weight of pulp $(\mathrm{g})$ & 162.3 & 173.1 \\
Weight of stone $(\mathrm{g})$ & 37.6 & 26.9 \\
\hline
\end{tabular}

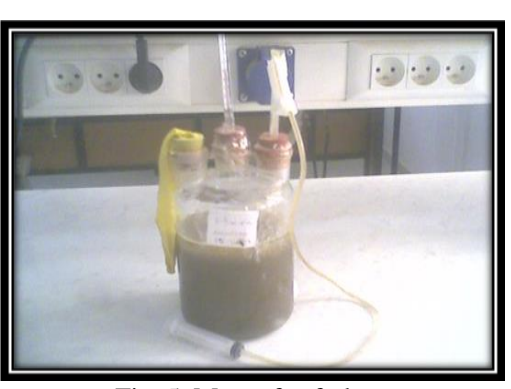

Fig. 5. Must of soft date.

Dilution of the pulps crushed by the water, the prepared solution is called must of date (Fig. 5).

Fermentation is made in anaerobic during 72 hours. Each 24heures, one takes a quantity of must fermented to measure the following parameters and especially to detect the odor of alcohol in must.
During fermentation we followed the following parameters [13]:

- acidity of must using an indicating $\mathrm{pH}$ paper,

- temperature of the bain-marie;

- temperature of the reactor;

- The rate of glucose and protein;

- Followed evolution of the color and odor of must; After $72 \mathrm{H}$ of fermentation we stop the reaction.

\section{RESULTS AND DISCUSSION}

The western southern area of Algeria annually produces an important tonnage of dates, approximately 675 miles quintals per year. These dates present a low commercial value, they are intended for subsistence farming, the animal feeds or the exchange in the form of barter towards Mali and Niger [3]. On the other hand, no processing industry of date, is established in the area.

For this reason these dates constitute a substrate of choice for the production of bioalcohol, The ethanol of vegetable origin is anything else only of ethanol, It can be mixed with the gasoline in proportions going from 5 to $85 \%$. Beyond $20 \%$, adaptations to the engines of cars are often necessary [7]. According to many experts and certain Western governments, the biofuels, and in particular bioalcohol, produce less emission of $\mathrm{CO}_{2}$ which is one of principal gases for purpose of greenhouse, from where the environmental stake is preserved, in our case the ethanol produced at the laboratory presents an output of $87 \%$ [8], [9].

Results of the first test; for soft dates of mass $200 \mathrm{~g}$; are recorded in the Table VII.

TABLE VII: RESULTS OF THE FIRST TEST OF ALCOHOLIC FERMENTATION

\begin{tabular}{ccccc}
\hline Time $(\mathrm{h})$ & $\mathrm{pH}$ & Glucose $(\mathrm{g} / \mathrm{l})$ & Protein $(\mathrm{g} / \mathrm{l})$ & $\mathrm{T}\left({ }^{\circ} \mathrm{C}\right)$ \\
\hline 00 & 5.5 & 300 & 0.3 & 32 \\
24 & 5.5 & 250 & 0.3 & 34 \\
48 & 5.5 & 10 & 0.05 & 31 \\
72 & 5.5 & 1 & 0.025 & 30 \\
96 & 5.5 & 0.5 & - & 30 \\
\hline
\end{tabular}

After filtration of the wine we recover a volume of the formed wine of $430 \mathrm{ml}$.

In the same way for dry dates of mass $200 \mathrm{~g}$, the follow-up of the kinetics of fermentation is recorded in Table VIII.

\begin{tabular}{ccclc} 
TABLE VIII: RESUlTS OF SECOND TEST OF AlCOHOLIC FERMENTATION \\
\hline Temps $(h)$ & $p H$ & Glucose $(g / l)$ & Protein $(g / l)$ & $T\left({ }^{\circ} \mathrm{C}\right)$ \\
\hline 00 & 6 & 10 & 0.05 & 30 \\
24 & 6 & 5 & 0.025 & 31 \\
48 & 6 & 2.5 & 0.0125 & 31 \\
72 & 5.5 & 0.01 & - & 31 \\
96 & 5.5 & 0.005 & - & 30 \\
\hline
\end{tabular}

We filter the solution obtained, the residue recovered at the bottom of the engine is dried then weighed, and the volume of the formed wine is $430 \mathrm{ml}$.

We weigh the weight of the residue of each varieties of dates.

Concerning the dry variety, we found a weight of the residue equalizes with 39,3g (Fig 6), on the other hand for the soft variety, the weight of residue is of $12.67 \mathrm{~g}$ (Fig 7);

The formed wine will undergo a series of distillation to increase the alcohol level extracted dates, for the first experiment by using $165 \mathrm{~g}$ soft dates of concentration of 
$300 \mathrm{~g} / \mathrm{l}$ of glucose, we produce a concentration of ethanol $280 \mathrm{~g} / \mathrm{l}$ i.e. a productivity of ethanol $3,88 \mathrm{~g} / \mathrm{L} / \mathrm{h}$. In the case of the date scrap dry of mass $173 \mathrm{~g}$, we found for a concentration of $100 \mathrm{~g} / \mathrm{L}$ of glucose, one produced $320 \mathrm{~g} / \mathrm{L}$ ethanol, with a productivity of $4,44 \mathrm{~g} / \mathrm{L} / \mathrm{h}$.

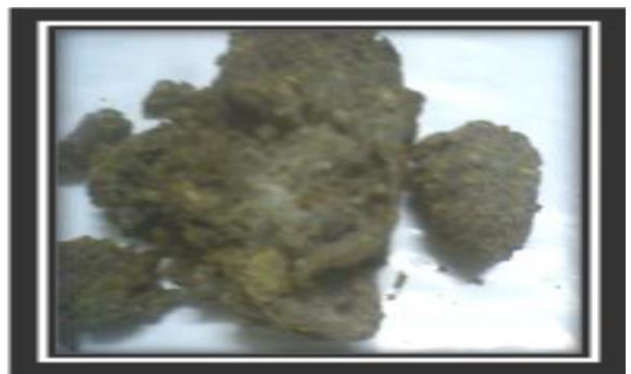

Fig. 6. Dry residue.

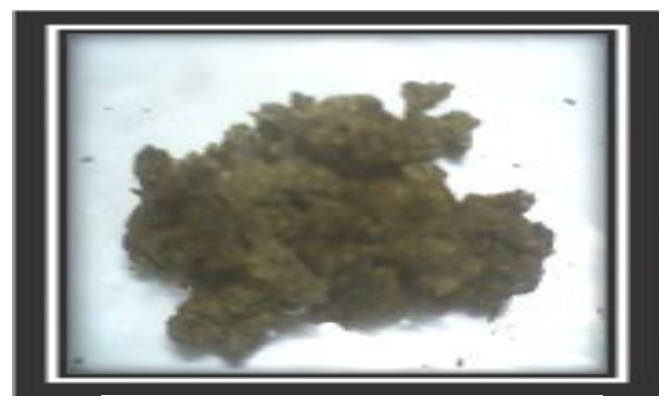

Fig. 7. Soft residue.

Fig. 8 exposes the ethanol produced by the two substrates, the date soft and the dry date [3].

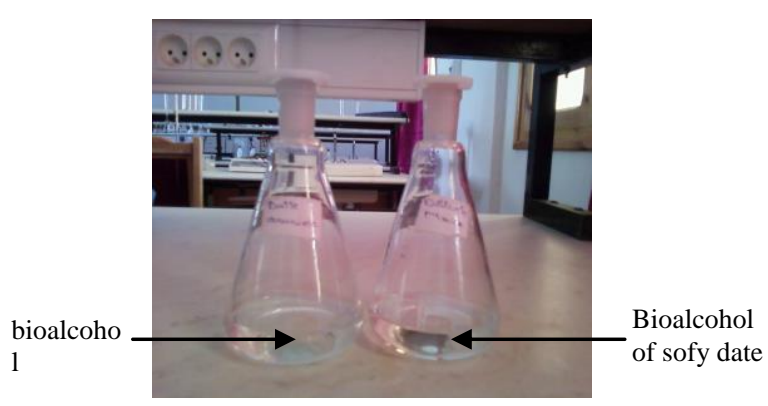

Fig. 8. Biaolcohol producted by the two varieties.

\section{CONCLUSION}

The South West region of Algeria annually produces a substantial tonnage of dates, approximately 675 miles quintals per year. These dates have a low market value, they are intended for the own consumption, animal feed or to the exchange in the form of barter to Mali and the Niger.

On the contrary, no industry of date transformation, is established in the region, for this reason these dates constitute a choice substrate for the production of the bioethanol, according to trials performed at the level of laboratory, fermentation in the presence of the yeast Saccharomyces cerevisiae, produced the ethyl alcohol with a satisfactory output and by medium alcoholic degree, this output can augment by working on the quantity of the yeast and the quality of distillation, it is the following stage of our research work.

\section{REFERENCES}

[1] M. Melikoglu, V. Singh, et al., Biochemical Production of Bioalcohols, Handbook of Biofuels Production, 2016.

[2] M. D. O. ElHadj, "Etude comparative de la productivité d'alcool brut de dates selon les varieties," Recherche Agronomique, no. 9, INA, Algérie, 2001.

[3] A. Boulal, B. Benali, M. Moulai, and A. Touzi, "Transformation des déchets de dattes de la région d'Adrar en biothanol," Revues des Energies Renouvelables, vol. 13, no. 3, 2010.

[4] K. Bousdira," Contribution de la biodiversité du palmier dattier pour une meilleure gestion et revalorisation de la biomasse: Caractérisation morphologique et biochimique de qualité des dattes cultivars les plus connus de la région du Mzab, classification et évaluation de la qualité," M.S.thesis, Univ Boumerdes, Algérie, 2007.

[5] R. H. M. Azhar, R. Abdullah, et al., "Yeasts in sustainable bioethanol production," A review, Biochemistry and biophysics Report, vol. 10, pp. 52-61, 2017.

[6] H. Zabed, J. N. Sahu, et al., "Bioethanol production from and technological renewable sources: current perpectives and technological progress," Renewable and Sustainable Energy Reviews, vol. 71, pp. 475-501, May 2017.

[7] E. Winkelhausen, E. Velickova, et al., "Production of bioalcohols by yeasts from Saccharomycess and Candida genera," Journal of Biotechnology, vol. 136, October 2008.

[8] O. J. Sanchez and C. A Cardona, "Trends in biotechnological production of fuel ethanol from different feedstocks," Bioressource Technology, vol. 99, no. 13, September 2008.

[9] N. Bouguedoura, "Connaissance de la morphogène du palmier, Etude in situ et in vitro du développement morphgénétique des appareils digestifs et reproducteurs," Ph.D. dissetation, USTHB, Alger, Algérie, 1991.

[10] M. Balat, H. Balat, et al., "Progress in bioethanol processing," Progress in Energy and Combustion Science, vol. 34, no. 5, October 2008.

[11] K. Seungdo and B. E. Dale, "Global potential production from wasted crops and crop residues," Biomass and Bioenergy, 2004.

[12] N. Laskri, A. Mizi, N. Nedjah, et al., "Biogas production from the anaerobic digestion of lignocellulosics wastes," Poll Res., vol. 35, no. 2, pp. 247-252, 2016.

[13] E. Espiado, "Introduction industrielle des fruits," Linear Networks and Systems, Belmont, CA: Wadsworth, pp. 123-135, 1993.

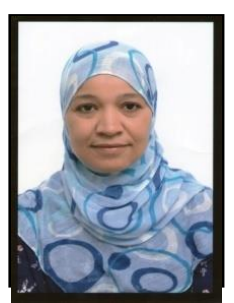

Nedjah Nawel was born on December 9, 1970 in Annaba, Algeria. She received her $\mathrm{PhD}$ at the Department of Process Engineering in 2016, she holds a magister degree in chemical engineering in 2002 at the Department of process engineering.

From 2003 to 2006, she worked as a researcher in renewable energy center, and then she moved to the university as a lecturer until to 2012. Now she occupies the position of a professor ESTI (Higher School of Industrial Technologies), Annaba, Algeria.

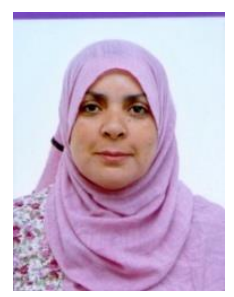

Laskri Nabila was born on November 20, 1969 in Annaba, Algeria. She received my $\mathrm{PhD}$ at the Department of Process Engineering in 2016, she hold a magister degree in chemical engineering in 2000 at the Department of Process Engineering, University of Annaba, Algeria.

From 2003 to 2005, she worked as a researcher in renewable energy center, and then she moved to the university as a lecturer until to 2012. Now she occupies the position of a professor at the ESTI (Higher School of Industrial Technologies), Annaba, Algeria. 